\title{
EXPERT REVIEWS
}

\section{Systemic lupus erythematosus, regulatory T cells and pregnancy}

\author{
Expert Rev. Clin. Immunol. 7(5), 635-648 (2011)
}

\section{Stephy Varghese', Ian Crocker ${ }^{1}$, Ian $\mathrm{N} \mathrm{Bruce}^{2,3}$ and Clare Tower $^{+1}$}

'Maternal and Fetal Health Research Centre, University of Manchester, St Mary's hospital, Manchester M13 9WL, UK

${ }^{2}$ Arthritis Research UK Epidemiology Unit, School of Translational Medicine, Manchester Academic Health Science Centre, The University of Manchester, Oxford Road, Manchester, UK

${ }^{3}$ The Kellgren Centre for

Rheumatology, Manchester NIHR Biomedical Research Centre, Central Manchester University Hospitals NHS Foundation Trust, Oxford Road, Manchester, UK

${ }^{+}$Author for correspondence: clare.tower@manchester.ac.uk

Systemic lupus erythematosus (SLE) is the most common autoimmune disease affecting women of reproductive age and is associated with poor maternal and fetal outcomes. CD4+CD25+ Treg cells are a subset of $\mathrm{T}$ lymphocytes with potent immunosuppressive activity that play crucial roles in controlling immunological self tolerance. Evidence suggests that they are augmented in pregnancy, especially in the first trimester, suggesting an important role in early placental development. The literature describing Treg cells in SLE is conflicting, but SLE is associated with reduced numbers and functionally defective Treg cells, which may predispose pregnant women with the disease to pregnancy complications. This article discusses the role of Treg cells in SLE and pregnancy, and how these cells may contribute to poor pregnancy outcome in SLE-affected women.

\section{KEYwoRDs: immune tolerance $\bullet$ pregnancy $\bullet$ systemic lupus erythematosus $\bullet$ T regulatory cells}

Systemic lupus erythematosus (SLE) is a multisystem autoimmune connective tissue disorder with a wide range of clinical manifestations including musculoskeletal, renal, cardiovascular, neuropsychiatric and pulmonary involvement, resulting in chronic debilitating ill health [1]. The reported overall prevalence of SLE in the population is approximately 52 in 100,000; but this varies significantly with ethnicity, age and gender [2]. The prevalence is increasing, probably due to a combination of better recognition of milder forms and improving survival rates. In the UK, inward migration of higher risk populations will also contribute to an increased prevalence.

Systemic lupus erythematosus is predominantly a disease of women of reproductive age. It is therefore of clinical importance in pregnancy and it is thought to affect approximately one to two out of every 1000 pregnancies [3]. During pregnancy, SLE is associated with significant maternal and fetal morbidity. Over the years, through a better understanding of the condition and a more multidisciplinary approach, more women with SLE are having successful pregnancies and delivering healthy babies [4]. Nonetheless, a recent systematic review and meta-analysis of pregnancy outcomes in patients with SLE still showed a $40 \%$ increased composite risk to the mother in the form of lupus flares, hypertension, nephritis and preeclampsia [5]. Fetal complications include loss from spontaneous early miscarriages at $16 \%$, while stillbirth and neonatal death rates compared with the normal pregnant population are increased by 3.1 and $2.3 \%$, respectively $[5,6]$. Overall, reported incidences for preterm delivery in SLE-affected pregnancies have ranged between 19 and $40 \%[5,7]$ compared with 5 and $10 \%$ in the general population [201].

Systemic lupus erythematosus and pregnancy are both associated with significant immunological changes. The underlying pathogenesis in SLE involves the formation of antibodies against certain self antigens, resulting in an ensuing inflammatory response that elicits a spiraling cycle of immune cell activation and tissue damage [7]. Conversely, pregnancy is an immunological balancing act in which the maternal immune system has to remain tolerant of paternal MHC antigens and yet maintain normal maternal immune competence for defense against microorganisms [8]. Within the adaptive and innate immune system, Treg cells have been shown to be critical for the development and maintenance of immune tolerance to self antigens. A disruption in the development/function of Treg cells notably causes severe autoimmunity and inflammatory 
disease in humans and animals [9]. These cells may therefore play an equal role in the pathogenesis of SLE and maternal tolerance and may thus provide a pathogenic link between SLE and complications in pregnancy. Of the numerous autoimmune diseases, some are typically ameliorated by pregnancy, such as rheumatoid disease and multiple sclerosis [10,11] but others, like SLE, are more prone to deteriorate [5]. In many ways pregnancy has been considered an immunosuppressive state, therefore, a positive effect on autoimmune diseases would be expected. The observation that SLE does not improve with gravidity, and is associated with an increased risk of pregnancy complications only highlights the limits of our current understanding.

\section{Immunology of pregnancy}

Since Medawar's hypothesis in 1953 it has long been recognized that in terms of the maternal immune system the conceptus is a semiallogenic tissue and, as such, should be automatically rejected [12]. In this context, Medawar proposed that anatomical separation of the embryo, fetal antigenic immaturity and maternal immunological inertness, were all reasons for fetal acceptance. These hypotheses have since been challenged as over simplistic; first, as maternal and fetal cells unquestionably do come into contact, with bidirectional transfer of cells in human placentation [13], and second, the maternal immune system is far from inert and undergoes significant changes throughout gestation [14].

\section{Implantation \& placental development}

The successful development of the placenta is vital for a healthy ongoing pregnancy. Failures during this complex process underpin the pathogenesis of a substantial proportion of pregnancy complications, including fetal loss, preeclampsia, fetal growth restriction and preterm delivery [15]. Following fertilization, and as a prelude to placentation, the blastocyst attaches and implants into the maternal decidua, the transformed endometrium (Figure 1). In order to facilitate implantation, decidualization begins during the late secretory phase of the menstrual cycle. This process, regulated by various hormones, including progesterone, involves the expansion of secretory glandules, the emergence of pinopodes (large apical protrusions) and microvilli on the luminal epithelium, alongside simultaneous modulations in the expression of various cytokines, chemokines, growth factors and adhesion molecules [16]. Within this milieu, maternal immune cells play an important regulatory role, representing the earliest interaction between the semi-allogenic fetus and the maternal immune response. Within the decidua, there is an accumulation of leukocytes within the stroma, predominantly natural killer (NK) cells. If conception occurs, the progesterone levels are maintained to facilitate placental development [17].

Within the gravid uterus, decidual NK ( $\mathrm{dNK}$ ) cells constitute $70 \%$ of maternal immune cells and play a recognized role in regulating the cellular interactions of decidualization [18]. Other immune cells include macrophages and dendritic cells, which make up $10-20 \%$ and $2-4 \%$, respectively, of resident leukocytes [19]. dNK cells are considered fundamentally different from circulating peripheral NK cells, in that they produce regulatory factors that facilitate implantation, rather than exhibiting a cytotoxic phenotype [20]. These cytokines, chemokines and angiogenic factors, including IL-8, IL-10, TGF- $\beta$ and VEGF, help control the complex processes of attachment, differentiation and invasion of placental trophoblast [21]. Other cytokines, such as the leukemia inhibitory factor (a member of the IL-6 family of proteins), produced by the endometrium, play essential roles in endometrial remodeling and low levels are associated with implantation failure [21].

Macrophages are the main antigen-presenting cells (APCs) in the human decidua, and in early pregnancy a proportion potentially differentiate into functional dendritic cells [22]. The defined role of decidual macrophages is incompletely understood, although they are generally believed to be immunosuppressive compared with circulating monocytes, as they inhibit T-cell responses in co-culture [23], produce large quantities of IL-10 [24] and express indoleamine 2,3 dioxygenase (IDO) [25], a known suppressor of T-cell proliferation [26].

Similar to dNK cells, uterine macrophages are implicated in placental transformation of maternal uterine vessels - that is, the conversion of decidual spiral arteries from narrow tightly coiled arterioles into large flaccid conduits for optimal fetal growth and development. Immunohistochemical studies demonstrate the presence of both uterine macrophages and dNK cells in the very earliest stages of spiral artery remodeling [27], which typically encompass the decidua and proximal third of the myometrium. Failures in this process, in which these physiological changes are shallow or incomplete, are observed in placentas from pregnancies complicated by miscarriage, preeclampsia and fetal growth restriction [15]. Decidual macrophages also release VEGF and soluble Fms-like tyrosine kinase-1 (sFlt-1), which again may assist in vessel modulation and angiogenesis [22]. Of the remaining leukocytes in human decidua, very few are B cells and approximately $10 \%$ are $T$ cells [28]. These include a proportion of immunosuppressive Treg cells.

\section{Treg cells \& pregnancy}

$\mathrm{CD} 4{ }^{+} \mathrm{CD} 25^{+}$Treg cells are immunosuppressive via their ability to inhibit IL-2 production, inhibit proliferation of $\mathrm{CD}^{+}$and $\mathrm{CD} 8^{+}$ $\mathrm{T}$ cells and suppress the function of APCs [29]. In general, these cells are described in the thymus (centrally occurring [Tregs]), in the periphery (naturally occurring [nTregs]) or can be induced from nonregulatory Treg cells (iTregs) (FIGURE 2) [30,31]. Likewise, their mechanisms of inhibition also differ, with centrally induced (thymic) Treg cells utilizing cell-cell contacts, and peripherally derived Treg cells utilizing cytokine-based mechanisms, particularly IL-10 [32].

In the past the identification of Treg cells has proved challenging. In 2003, forkhead/winged helix transcription factor (FOXP3) was described as a critical regulator of Treg cell development and function [33-35]. A few years later, Roncador et al. proposed FOXP3 as a specific intracellular marker for Treg cells [36]. FOXP3 is an inhibitor of DNA transcription and is highly expressed in $\mathrm{CD} 4{ }^{+} \mathrm{CD} 25^{+} \mathrm{T}$ cells at both the mRNA and protein level. The importance of FOXP3 as a master controller of Treg 


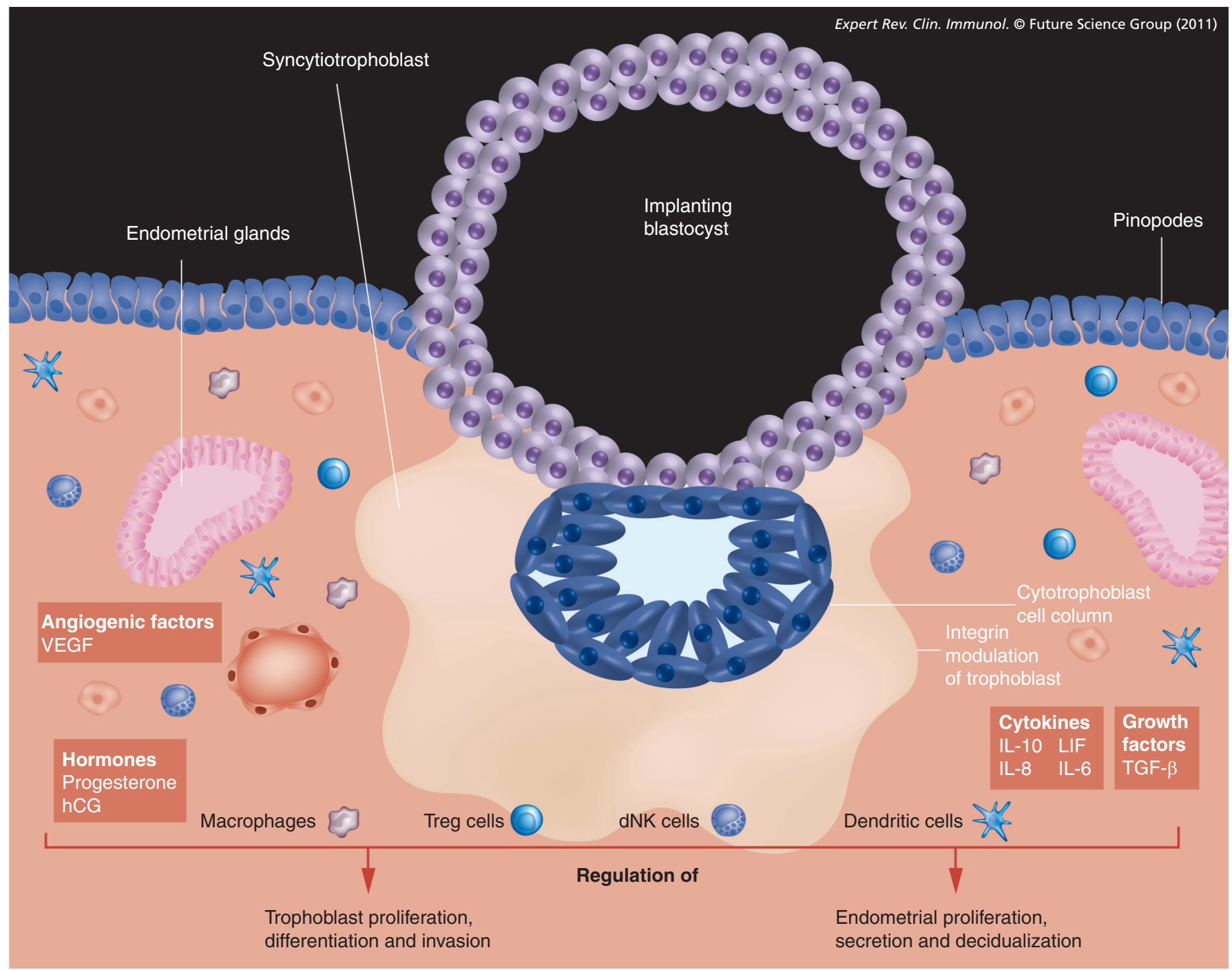

Figure 1. Blastocyst implantation. The blastocyst attaches and implants into the maternal decidua. This process is regulated by hormones, such as progesterone, the emergence of pinopodes on the luminal epithelium, and simultaneous modulations in the expression of cytokines, growth factors and angiogenic factors. A large body of evidence describes Treg cells in the decidua and it is suggested that several chemokines and hCG act as attractants for Treg cell ingress to the uterus. dNK: Decidual natural killer cell; hCG: Human chorionic gonadotrophin.

cell function is strikingly illustrated in individuals with FOXP3 deficiency, for instance, the X-linked immunodeficiency syndrome immune dysregulation, polyendocrinopathy, enteropathy, X-linked syndrome (IPEX) [37]. This syndrome, in which FOXP3 is mutated, causes autoimmune disease in multiple organs and is marked not only by a lack of $\mathrm{CD} 4{ }^{+} \mathrm{CD} 25^{+}$Treg cells, but also their significant dysfunction. Other potential surface cell markers for the identification of Treg cells are low levels of CD127 [38,39], and high levels of cytotoxic T-lymphocyte-associated molecule- 4 (CTLA4) and glucocorticoid-induced TNF receptor (GITR) [40] Recent studies have shown that $\mathrm{FOXP} 3{ }^{+} \mathrm{CD} 4{ }^{+} \mathrm{T}$ cells can be subdivided into subpopulations based on their cell surface markers, such as the CD 45 isoforms CD45RA and CD45RO [41-43]. There is now additional evidence that FOXP3 cells in human peripheral blood have a heterogeneous function and include suppressive and nonsuppressive T cells [44]. Thus, the expression of
CD45RA or CD45RO, which are mutually exclusive in FOXP3+ cells, are suggested as better markers of Treg cells when combined with CD25/FOXP3 positivity [45]. CD45RA is a proposed marker for naive Treg cells that emigrate from the thymus and become converted to $\mathrm{CD}_{45 \mathrm{RO}^{+}}$effector Treg cells upon FOXP3 activation $[43,46,47]$.

Initial studies suggested that approximately $14 \%$ of the $\mathrm{CD}^{+}$ $\mathrm{T}$ cell population in human term decidua were $\mathrm{CD} 4^{+} \mathrm{CD} 25^{+}$ cells [25]. Since most of these expressed CTLA-4 and GITR, the authors concluded that these were likely Treg cells. This study predated the description of FOXP3 and a more recent study, using first trimester decidua obtained from elective termination of pregnancy [48], confirmed the presence of Treg cells, using FOXP3, $\mathrm{CD} 127^{\mathrm{dim}}$, CTLA- 4 markers, in addition to $\mathrm{CD} 4{ }^{+} \mathrm{CD} 25^{+}$. In the peripheral circulation these cells were found to be $0.5-0.7 \%$ of the total lymphocytes, and 4 and $10.5 \%$ in the decidua basalis 


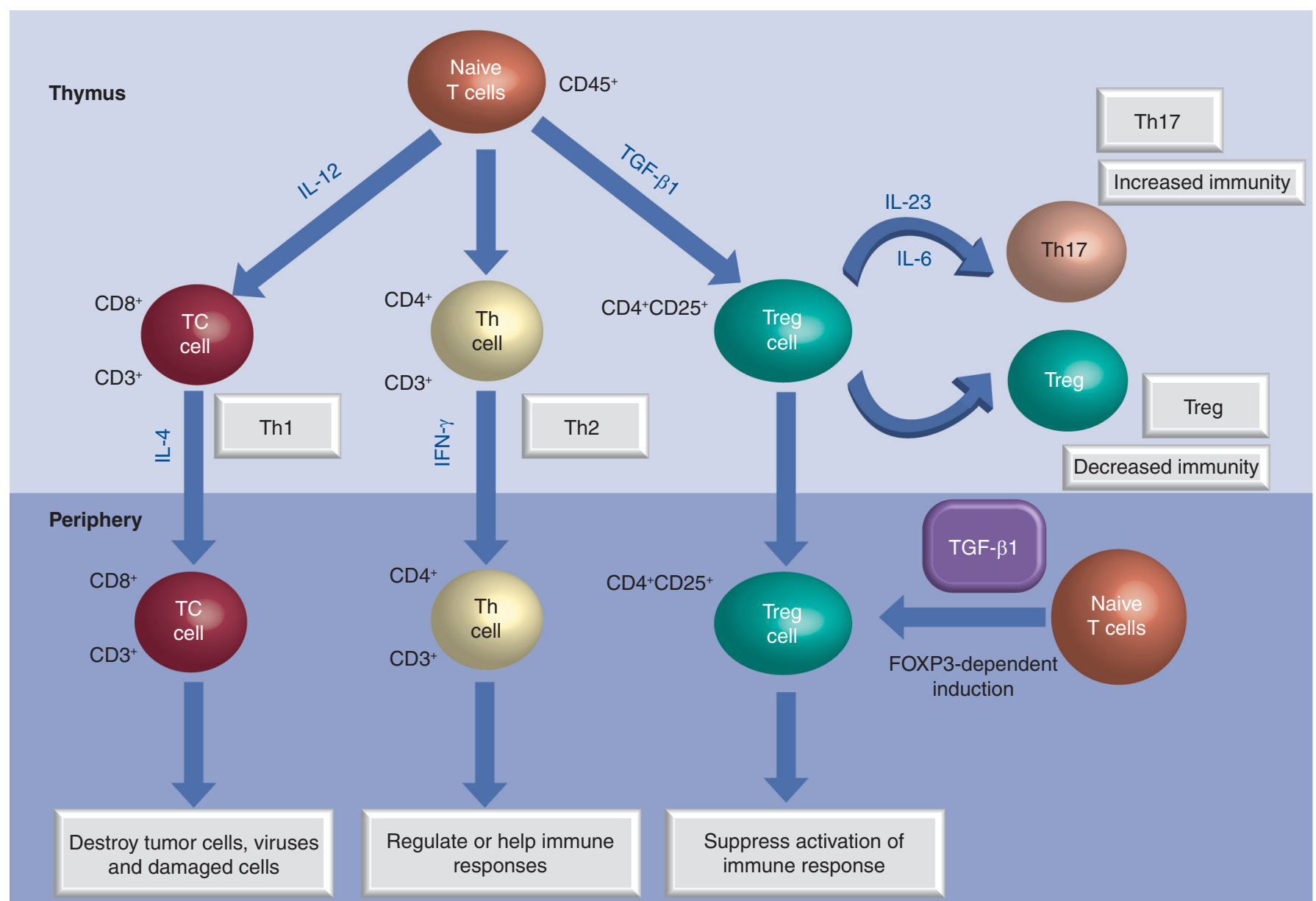

Expert Rev. Clin. Immunol. @ Future Science Group (2011)

Figure 2. The origin of Treg cells. Naive T cells originate in the thymus and differentiate into T-cell subsets. They are characterized by cell surface markers and are regulated by cytokines. Treg cells can be induced in the periphery by TGF- $\beta$ via expression of FOXP3. Treg cells and Th17 cells both require TGF- $\beta$ for differentiation. There is a reciprocal relationship between Th17 cells and Treg cells. TGF- $\beta$ induces Treg-specific FOXP3, while the addition of IL-6 inhibits this process in favor of Th17 induction. A fine balance between Th17 and Treg cells is crucial for immune homeostasis.

TC: Cytotoxic T; Th: T helper.

and parietalis, respectively [49]. With regards to the fetal immune system, some studies report that maternal alloantigens promote the proliferation of fetal Treg cells in utero [50]. The frequency of fetal Treg cells in cord blood decreases with gestation from 15 to $20 \%$ of total $\mathrm{CD}^{+}{ }^{+} \mathrm{T}$ cells at $12-20$ weeks of pregnancy to $3-7 \%$ at birth [51].

Although there is a paucity of data pertaining to human pregnancy, there is considerable evidence describing a role for Treg cells in murine pregnancy. Mouse pregnancy is marked by an increase in $\mathrm{CD}^{+} \mathrm{CD} 25^{+} \mathrm{FOXP} 3^{+}$cells both in the uterus and peripheral circulation [52]. The trigger for this expansion is partly hormonal, as Treg cells increase during the follicular phase of the murine estrous cycle [53], but also driven by paternal antigens, as an increase in paternal antigen-specific Treg cells is observed in murine lymph nodes draining the uterus 3 days after mating [54]. In addition, several uterine chemokines have been described as potential chemoattractants for Treg cells [55]. A recent study of human cells suggested that human chorionic gonadotrophin (hCG), secreted by trophoblast at the implantation site, may also represent a further stimulus for uterine Treg cell migration [56].

\section{Systemic maternal response}

Following conception, significant maternal physiological changes occur in order to accommodate the growing fetus. Concomitant changes in the maternal immune system are regulated by $\mathrm{T}$ cells, and these are associated with adjustments to the cytokine milieu (see Figure 3 for overview). Originally it was conceived that Th2 cytokines predominate (IL-4, IL-5, IL-10, IL-13 and granulocyte-macrophage colony-stimulating factor [GM-CSF]) and that Th1 cytokines (IL-1, IL-2, IL-6, IL-12, IL-15, IL-18, IFN- $\gamma$ and TNF- $\alpha$ ) were suppressed [57,58]. Consequently, the balance between the Th1 and Th2 response was considered a survival mechanism for the fetus and that in pregnancy complications, such as miscarriage, preterm labor and preeclampsia, this balance 


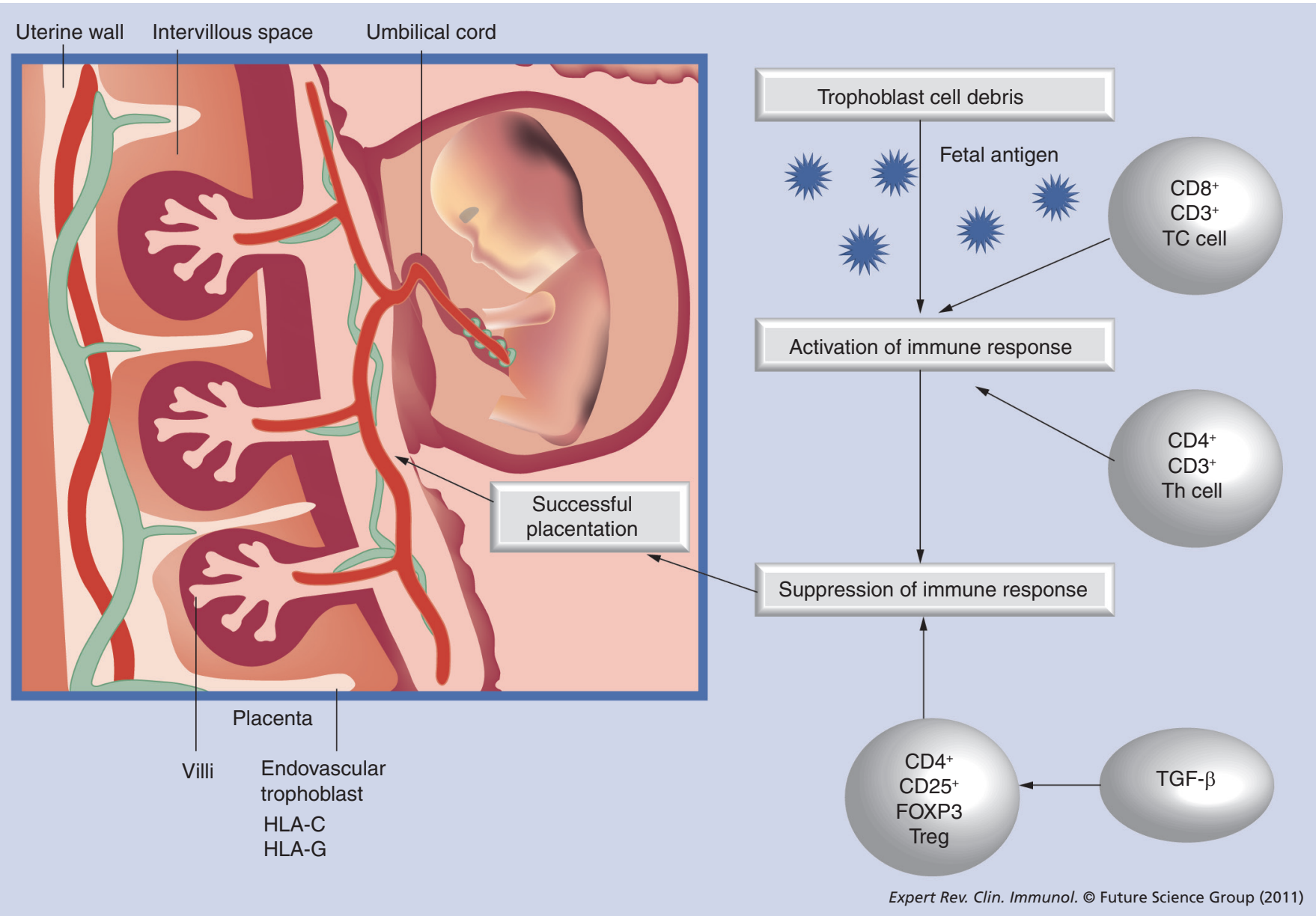

Figure 3. Fetal tolerance. The semi-allogenic fetus evades immune rejection by the maternal immune system by several mechanisms. One of the most important evasive strategies is the absence of classical MHC class I antigens HLA-A and HLA-B on trophoblast of placental origin. Endovascular trophoblast cell subsets express a unique subset of MHC class I products, HLA-C and HLA-G. Debris from apoptotic trophoblast cells is released into maternal peripheral blood and activates the maternal immune system. Subsequently, activated FOXP3 ${ }^{+} \mathrm{CD} 4{ }^{+} \mathrm{CD} 25^{+}$Treg cells induce tolerance to specific fetal antigens by suppressing immune activation.

TC: Cytotoxic T; Th: T helper.

was tipped in favor of Th1 activity [59]. More recently this Th1/ Th2 hypothesis has been questioned, as normal pregnancies were observed in mice that lack Th2 cytokines and Th2 cytokine dominance was reported in some cases of recurrent miscarriage [60]. Furthermore, peripheral blood monocytes from women with recurrent miscarriage were found to produce lower levels of Th2 cytokines than those from healthy women [61]. These more detailed observations suggest that the Th1/Th2 hypothesis is oversimplistic and that additional factors must be involved.

In addition to uterine Treg cells, early reports of murine models propose an additional role for circulating Treg cells in pregnancy, with an increase in gestation and absence in pregnancy failure [52]. Human studies have confirmed this dependence, with levels increased in early pregnancy, peaking during the second trimester and declining postpartum [62]. Others have described this increase [63-65], while in contrast some have reported no change [49] or even a fall in the second trimester [66]. This discrepancy is probably due to differing patient populations and small study numbers, but may predominantly reflect alternative methods of identification, using different antibodies and flow cytometric approaches. Despite these inconsistencies, the overwhelming likelihood, taking both human and murine data together, suggests that pregnancy is associated with a rise in these immunosuppressive cells in the both the decidua and peripheral circulation [67].

\section{Th17 cells and pregnancy}

Th17 cells are a further population of $\mathrm{T}$ cells, defined by their ability to produce IL-17, which, like Treg cells, are implicated in pregnancy. Th-17 cells are proinflammatory and generally have opposing actions to Treg cells. As such, they have suggested importance in autoimmune disease [68]. With the new recognition of these cells, the typical Th1/Th2 paradigm of pregnancy has now been expanded [69], with Th1, Th2 and Th17 cells suppressed by Treg cells [70]. Interestingly, Treg and Th17 cells both require TGF- $\beta$ for differentiation, and a reciprocal relationship has been described [69]. Although TGF- $\beta$ is required for the generation of peripheral Treg cells, via expression of FOXP3 [71], the added 
presence of IL-6 appears to favor the generation of Th17 cells [72]. It is also apparent that Treg cells can differentiate directly into Th17 cells and that this process is dependent upon the immunomodulatory enzyme IDO. In the presence of IDO, the immunosuppressive Treg phenotype is maintained, but blockade of IDO converts Treg cells to a Th17 phenotype [73].

There is little work investigating the presence of Th17 cells directly in the human decidua, although the inverse relationship between Treg and Th17 cells seems to be maintained [48]. For circulating Th17 cells, one study suggests no change in healthy pregnancy with gestation [74], while another proposes a reduction in the third trimester compared with nonpregnant individuals, with a resulting increase in the Treg:Th17 cell ratio [75]. Clearly more work is needed to investigate the role of Th17 cells in healthy pregnancy, especially the complex interplay between these T-cell subtypes [69].

\section{The role of Treg cells in SLE}

Systemic lupus erythematosus is a classic autoimmune disease characterized by autoantibody production, immune complex deposition and end-organ damage. The pathogenesis of SLE includes both insufficient immune regulation of $\mathrm{T}$ cells and altered B-cell function [76]. The breakdown in T-cell-mediated tolerance and the generation of antinuclear antibodies (ANAs), including antibodies to dsDNA and Smith antigen have been consistently reported [77].

Experiments in mice have demonstrated that normal rodents depleted of $\mathrm{CD}^{+}{ }^{+} \mathrm{CD} 25^{+} \mathrm{T}$ cells develop severe autoimmune pathology, and that reconstitution of their Treg population inhibits this autoimmunity [78,79]. In accordance with this, Sakaguchi et al. noted that, by day 3, thymectomized mice developed organspecific autoimmune disease [80]. Depletion of Treg cells in some varieties of mice will accelerate the onset of glomerulonephritis [81], whereas studies in lupus-prone mice showed that these cells were decreased before glomerulonephritis appeared [82,83]. One group estimated that the pool of Treg cells in lupus-prone mice (BWF1) is $40-50 \%$ that of their phenotypically normal counterparts [83] and another reported that T cells from an alterative SLE model (MLR/lpr) were resistant to T-cell suppression [84]. The ablation of Treg cells in FOXP3-deficient mice also generates an autoimmune disorder (Scurfin) [85], while a delay in disease onset in BWF1 mice after transfer of expanded $\mathrm{CD} 4{ }^{+} \mathrm{CD} 25^{+}$cells reinforces the importance of Treg cells and demonstrates their potential for altering the course of disease [85]. The therapeutic effect of exogenous Treg cells, delivered via various routes (nasal, subcutaneous, intravenous), has been shown in mouse models to increase Treg cell numbers, delay disease onset [86] and prolong survival [87].

Human literature shows conflicting data on the frequency, phenotype and functional properties of Treg cells in SLE [88]. The majority of studies have shown decreased numbers [89,90], with some groups reporting an inverse correlation with disease activity [91]. A few studies have specifically demonstrated reduced Treg cell numbers in SLE patients of clinically active disease compared with healthy controls, but not in inactive SLE patients [90,92,93]. It has also been reported that, while nTreg cells are decreased in SLE patients, iTreg cells are higher than healthy controls [89]. In contradiction, a minority of studies have shown an increased frequency of Treg cells with SLE [94,95] and some have shown no change [96-98]. To some extent, these discrepancies may be due to the heterogeneity of patient populations and criteria chosen for Treg cell definition, with studies before 2007 using the $\mathrm{CD} 4{ }^{+} \mathrm{CD} 25^{+}$phenotype and those after including FOXP3 positivity. As suggested, some groups argue that additional markers are also necessary [99,100].

A potential confounder in any human studies in SLE is medication and the acquired effects from immunosuppressive drugs. Although some studies have shown a subsequent increase in number and frequency of $\mathrm{CD} 4{ }^{+} \mathrm{CD} 25^{+} \mathrm{FOXP} 3$ Treg cells in new-onset patients prescribed corticosteroids or choloroquine [95], this observation could arise through a reduction in disease activity, rather than direct Treg cell effects per se. In one study, on administration of rituximab in active lupus nephritis; mRNA levels of CD25, CTLA-4, GITR and FOXP3 increased significantly. The FOXP3 mRNA persisted in clinical remission, but gradually decreased in active patients [101].

A number of mechanisms have been proposed for Treg cellmediated suppression in vitro and in vivo. In vitro, most studies have demonstrated that Treg cells mainly mediate suppression by inhibiting the induction of IL-2 mRNA in the responder FOXP3- T cells [102-104]. Another suggested suppressive mechanism is cytolysis of target cells, where activated FOXP3 ${ }^{+} \mathrm{T}$ cells function as cytotoxic cells [105]. The blocking of the binding protein galectin-1 has also been proposed to reduce the inhibitory effect of human and mouse Treg cells [106]. In vivo, Treg cells can suppress immune responses at multiple levels [107]. Animals with selective deletion of CTLA-4 develop systemic autoimmunity. It has been proposed that CTLA-4 downregulates the costimulatory molecules CD80 and CD86, preventing dendritic cells from stimulating naive T cells [108]. One mechanism by which Treg cells exert their function in vivo was defined by DiPaolo et al., who used TGF- $\beta$-induced Treg cells to prevent gastritis in mice [109]. The authors proposed a mechanism where Treg cells inhibited the stimulatory effects of dendritic cells to prime autoreactive T cells, hence blocking the autoimmune reaction before it started. Although there are multiple mechanisms of Treg cell suppression in vitro and in vivo, the argument is whether they are different in both environments and ultimately whether they can they be manipulated successfully in the latter.

There is growing interest in Th17 cells in SLE and there are several studies reporting an increase in Th17 numbers and IL-17 in affected patients [59,89-92]. Flares and more severe forms of the disease, such as lupus nephritis and vasculitis, appear to be associated with a more marked increase in Th17 cells [110] and the balance between Treg cells and Th17 may be further distorted, with the Treg:Th17 cell ratio lowered in patients suffering a flare compared with those with inactive disease $[110,111]$. As discussed, TGF- $\beta$ plays a significant role in the differentiation of both Treg cells and Th17 cells. In a large cohort study of SLE patients, reduced levels of TGF- $\beta 1$ were consistently associated with increased disease activity and susceptibility [112]. It therefore seems logical that SLE is associated with a reduction in immunosuppressive 
Treg cells and TGF- $\beta$, and a concomitant increase in the proinflammatory Th17, and that the balance between these factors correlates appropriately with disease activity.

\section{Pregnancy complications \& SLE}

Pregnancy in women with SLE is associated with considerable maternal and neonatal morbidity and mortality [113], with the risk of maternal death 20-fold higher [114], through complications of preeclampsia, thrombosis, infections and hematological abnormalities. This increased risk persists when adjusted for maternal age. As discussed, optimal development of the placenta is a prerequisite for a successful pregnancy, and failures can underpin common pregnancy complications. However, there is surprisingly scant literature pertaining to placental abnormalities in SLE. Notwithstanding, placentas from patients with SLE have been described as smaller than in healthy pregnancy, and to contain intraplacental hematomas, deposition of immunoglobulin (including ANA), complement protein and thickening of the trophoblast basement membrane [115,116]. Reduced placental size is particularly correlated with poor pregnancy outcome. Histological studies of decidual vessels in SLE often show acute atherosis, an appearance likened to transplant rejection, and this has been reported in association with miscarriage [117].

Placental pathology in cases of SLE is common in women with antiphospholipid antibodies [115]. A few studies have investigated in vitro the effects of sera from women with SLE on embryo and placental tissue cultures. In this context, culture of rat embryos in the presence of human sera from women with SLE and recurrent pregnancy loss resulted in increased embryonic death and abnormality [118]. This same study investigated the effects on human placental tissue (trimester unspecified) and demonstrated reduced proliferation and increased apoptosis - an observation later confirmed on first trimester trophoblast [119]. This group also reported a reduction in trophoblast production of hCG in the presence of SLE sera, and that this reduction was most marked in women with additional antiphospholipid antibodies [120]. It is therefore apparent that placental pathology is a feature of pregnancy in women with SLE and that given the importance of immune cells in the development of the placenta, immune dysfunction in these women may understandably make a significant contribution.

Although there is conflicting evidence regarding the risk of flare in pregnancy, overall it seems that flare or active disease at conception or even preconception (6-12 months before) is associated with worsening outcome, with an exaggeration of SLE symptoms and risk of fetal loss, preterm birth and cesarean section [121,122]. In the Hopkins Lupus pregnancy cohort, increased lupus activity was associated with a still birth rate of $16 \%$, and extreme ( $<28$ weeks gestation) and late preterm delivery (between 28 and 37 weeks) of 17 and 49\%, respectively [123]. Disease flare correlates with marked immune aberrations, with the greatest changes in Treg and Th17 cells [111]. Given this, it could be conceived that these changes may have the greatest impact in the early stages of pregnancy, when abnormal placentation lays the foundations for later pregnancy complications. This clinical observation further emphasizes the potential role of immune dysfunction in SLE, as associated with pregnancy.
The number of Treg cells, both in the peripheral circulation and decidua, are reduced in women with spontaneous and recurrent miscarriage (i.e., three or more consecutive losses), with and without antiphospholipid antibodies [63,124-127]. This coincides with a corresponding increase in Th17 cells, even in the decidua of pregnancies of inevitable miscarriage (i.e., those with an already failed pregnancy presenting with symptoms) [128]. A study of women with unexplained recurrent miscarriage found that their Treg cells were less able to inhibit IL-17 production compared with healthy controls [124]. Pregnancy loss has also been investigated in mouse models of Treg cell deficiency - these mice miscarried allogeneic pregnancies but not syngeneic ones [52]. Similarly, administration of anti-CD25 antibody to pregnant mice reduced the levels of Treg cells by up to $60 \%$ and again induced allogeneic miscarriage [129]. Notably, the adoptive transfer of CD $4^{+} \mathrm{CD} 25^{+}$cells from normal pregnant mice to deficient mice prevents miscarriage, but only if performed before 4 days postconception [130]. These murine studies emphasize the importance of intact immunological function at the earliest stages of implantation and placental development, and highlight normal Treg cell numbers and function as a prerequisite for healthy ongoing pregnancy.

Systemic lupus erythematosus is associated with a particular risk of preeclampsia, raised from $<5 \%$ in a normal population to between 22 and 30\% [131,132]. Preeclampsia is largely a placental disease, defined as new-onset hypertension and proteinuria after 20 weeks gestation [133]. Women with lupus nephritis are at particular risk. Preeclampsia is associated with maternal immune dysfunction and a predominance of Th1 cytokines [134]. Although two small studies failed to show changes in Treg cells in preeclampsia [135,136], others report a reduction in circulating numbers at the time of diagnosis, utilizing additional FOXP3 expression [137] and a concomitant reduction in the utero-placental bed [138]. A further study, using similarly robust methods, confirmed lower levels, but also reported similar functional results between normal and preeclamptic pregnancies [75]. IL-17-producing cells in this latter case were reduced in the uncomplicated pregnancies, but retained in those with preeclampsia, suggesting a Treg cell:Th17 imbalance. Others have also reported increased numbers of Th17 cells in preeclampsia [139]. It is now well established that preeclampsia is associated with poor placental angiogenesis, possibly due to increased levels of sFlt- 1 and soluble endoglin [140]. Soluble endoglin inhibits signaling of TGF- $\beta$, which, as described, is a key control mechanism in determining Treg and Th17 cell differentiation. Thus, the increased levels of endoglin in preeclampsia, together with increased IL-6 (also observed [141]), may lead to reduced TGF- $\beta$ signaling, resulting in the promotion of Th17 differentiation and dominance.

There are few studies investigating preeclampsia in pregnant women with SLE. It is believed that the placenta in pregnancies destined to be affected by preeclampsia produce increased amounts of sFlt-1 (sVEGFR-1) [142]. sFlt-1 binds to VEGF and placental growth factor (PlGF), thus inhibiting their signaling and potentially leading to the syndrome. A retrospective study of 52 stored serum samples from pregnant women with SLE was able to demonstrate increased levels of sFlt- 1 in 18 women who later developed preeclampsia [143]. There is also evidence that sFlt-1 is able to inhibit 
TGF- $\beta$ signaling [144], suggesting that increased sFlt- 1 may also be associated with a deranged Treg/Th17 cell balance. The Predictors of Pregnancy Outcome in Systemic Lupus Erythematosus and Antiphospholipid Syndrome (PROMISSE) study, which is investigating potential biomarkers for poor pregnancy outcome in women with SLE and/or antiphospholipid antibodies, recently reported an association between loss of function polymorphisms in factors controlling complement activation and preeclampsia [145]. The odds ratio was 8.1 , although the $95 \%$ confidence range was wide (1-69). The same group demonstrated that complement activation in mice leads to placental and endothelial damage, and that C5 activation leads to the release of sFlt-1 [146]. While first reports of genetic associations must be interpreted with caution, these studies add further support to the complex interactions of regulatory elements of the immune system and circulating factors that underpin the pathogenesis of preeclampsia in women with SLE.

Treg cells have been investigated in other autoimmune diseases during pregnancy. Rheumatoid arthritis (RA), unlike SLE, is typically associated with an improvement in disease activity with gestation. Forger et al. showed significantly higher frequencies of Treg cells in patients with RA during pregnancy than compared with 8 weeks postpartum [147]. They observed that the amelioration of disease activity in the third trimester corresponded to increased numbers of Treg cells, inducing a pronounced anti-inflammatory response. The same group reported similar Treg frequencies in pregnant patients with ankylosing spondylitis (AS), but with a significant reduction in IL-10 secretion [148]. These studies highlight how pregnancy-related changes in Treg cells and their anti-inflammatory cytokines may have notable benefits in autoimmune activity.

To date, Treg cells have not been directly investigated in pregnant women with SLE. Our own preliminary data have shown that circulating $\mathrm{CD} 4{ }^{+} \mathrm{CD} 25^{+} \mathrm{FOXP} 3$ Treg cells are markedly reduced in quantity in nonpregnant women with SLE compared with healthy counterparts and that these levels remained depleted in SLE patients when pregnant, with those in healthy individuals raised, most strikingly at 10-12 weeks gestation [64]. Notably, the women in our study had mild disease, as defined by the British Isles Lupus Assessment Group and SLE Disease Activity Index scales, and that Treg cell depression was evident, regardless of disease activity and medication. This study reinforces the idea of required Treg cell elevations in early pregnancy and highlights a potential trigger for pregnancy complications.

\section{Expert commentary}

The emergence of Treg cells as a key player in autoimmune disease and pregnancy has generated interest in its potential role in disease management and associated pregnancy complications. The understanding of Treg cell generation, expansion and migration pathways is in its infancy. However, the importance of these cells for disease activity and normal pregnancy has been routinely demonstrated both in mouse models and humans. Specifically, reduced Treg numbers are associated with the emergence of autoimmunity and these reductions seem to persist in pregnancy, despite gestational expansion. The knowledge that Treg cells can be induced in the periphery via TGF- $\beta$ raises obvious therapeutic possibilities. However, given that TGF- $\beta$ can also induce Th17 cells, this approach may be somewhat naive, and a far greater understanding of these cells, their cytokines and control mechanisms is undoubtedly required.

\section{Five-year view}

Although initial work has suggested the importance of Treg cells in SLE and pregnancy, further studies are warranted. Ideally these studies should start preconceptually and be followed throughout gestation and postnatally. Also, the roles of cytokines and other regulatory factors driving the activation and expansion of Treg cells in early pregnancy should be refined, as well as factors that regulate recruitment and retention of these cells to the uterus. As Treg cell markers vary in existing studies, there is a continued need for consistency in cell identifiers.

The pivotal role of Treg cells in pregnancy and SLE, and their association with pathological states, makes this pathway an attractive prospect in terms of new therapeutic options. Established therapies for SLE such as corticosteroids have been shown to increase quantities of Treg cells. However, our own group report that despite such treatment, women with SLE still have persistently lower Treg cell numbers [64].

The knowledge that Treg cells can be induced peripherally has been employed in several strategies for increasing Treg cell activity in tissue transplantation therapies and treatments for autoimmune disease [149]. The potential of Treg cell therapies has been explored in various ways, including increasing their numbers/function by prior isolation and in vitro differentiation and expansion. Most of these experiments were performed in animal models. In some of these, a number of pharmacological agents, such as rapamycin [150], glatiramer acetate [151] and trichostatin A [152], have been shown to induce and/or expand Treg cell numbers. In humans, however, much less is known.

Interest in the application of Treg-based treatments for reproductive problems, such as infertility and recurrent miscarriages is also increasing. As such, the augmentation of Treg cells around the time of implantation has shown promise in murine models [153]. In this study, Zenclussen et al. demonstrated that Treg cells from pregnant and nonpregnant mice could inhibit proliferation and IFN- $\gamma$ secretion of lymphocytes from miscarriage-prone mice in vitro [153]. Moreover, the in vivo prevention of fetal rejection could be achieved, but only after adoptive transfer of Treg cells from pregnant mice. Interestingly, the in vivo prevention of fetal rejection could be achieved only after adoptive transfer of Treg cells from pregnant mice, not nonpregnant donors. This implies that only Treg cells exposed to paternal alloantigens possess protective regulatory activity.

Vaginal application of TGF- $\beta$ has also proven to augment Treg numbers in the periphery and reduce fetal loss in CBA/J X DBA/2J mice models otherwise prone to miscarriage [154]. In this context, the effect of TGF- $\beta$ on fetal loss appears dose dependant with higher doses up to $200 \mathrm{ng}$ being most effective.

Another reported approach for driving endogenous Treg cell production has been the administration of granulocyte colonystimulating factor (G-CSF), which improved pregnancy rates in a small group of women with recurrent miscarriages [155]. G-CSF is a 
cytokine, expressed and produced by the decidual cells, that stimulates neutrophillic granulocyte proliferation and differentiation. In this study, it was subcutaneously administered daily from day 6 ovulation until 9 weeks gestation. There were no adverse maternal or fetal effects, but experimental models in animal studies with much higher doses have reported placental embolism [156].

Most of the aforementioned treatments are experimental and should not be used in the absence of rigorous clinical trials, as substances that show encouraging results in animals do not necessarily produce the same effects in humans. In this respect, Suntharalingam et al. reported an adverse systemic inflammatory response in young healthy volunteers administered monoclonal antibody to CD28, TGN1412, which should have expanded the Treg population. The responses ranged from headaches and diarrhea to renal failure and disseminated intravascular coagulation [157].

\section{Conclusion}

An increasing number of women with SLE are attempting pregnancies in recent years and, with a multidisciplinary approach, successful pregnancy outcomes have increased. Nevertheless, these women still face high complication rates with increased maternal and fetal morbidity and mortality.

Collectively, the emerging evidence provides a compelling case that Treg cells play an important role in successful pregnancy, especially as they peak in the first trimester. This implies that
Treg cells may be essential for the initial placental invasion of maternal decidua during early pregnancy. The hypothesis that women with SLE have a dysregulation of Treg cells and TGF- $\beta$, resulting in an inability to increase Treg cell numbers to levels required to support a healthy viable pregnancy, is therefore worthy of further investigation.

Future efforts should be targeted at understanding the functions and dynamics of Treg cells in pregnancy. Likewise, the role of cytokines and regulatory factors that drive the activation and expansion of Treg cells in early pregnancy, as well as factors regulating recruitment and retention of these cells to the uterus, need further definition.

Although still in its early stages, the study of Treg cells will significantly enhance our knowledge of fetal tolerance. Furthermore, these cells themselves may eventually become a powerful tool for the obstetric management of SLE patients.

\section{Financial \& competing interests disclosure}

All authors are supported by the Manchester Academic Health Sciences Centre and Manchester NIHR Biomedical Research Centre. Clare Tower and Ian N Bruce are also funded by the Manchester Wellcome Trust Clinical Research Facility. The authors have no other relevant affliations or financial involvement with any organization or entity with a financial interest in or financial conflict with the subject matter or materials discussed in the manuscript apart from those disclosed.

No writing assistance was utilized in the production of this manuscript.

\section{Key issues}

- Systemic lupus erythematosus (SLE) is a chronic, multisystem, inflammatory connective tissue disorder that occurs predominantly in young women.

- T-regulatory (Treg) cells play a pivotal role in maintaining immunological homeostasis to self antigens and in suppressing excessive immune responses deleterious to the host.

- In pregnancy, adaptation of the maternal immune response to accommodate the semi-allogeneic fetus is a necessity.

- Treg cells expand in normal pregnancy in the first trimester, peak in the second trimester and decline postpartum.

- Treg cells are elevated in the endometrial decidua compared with the peripheral blood suggesting a role in placentation.

- Pregnancy in women with SLE is associated with considerable maternal and neonatal morbidity such as miscarriage, preeclampsia and fetal growth restriction.

- Treg cells are reduced in autoimmune diseases and in pregnancies complicated by preeclampsia and preterm labor.

- Th17 cells show a reciprocal relationship with Treg cells in maintaining immune homeostasis and their differentiation is dependent on TGF- $\beta$.

- Treg cells may have the potential to be exploited as a therapeutic tool to combat pregnancy complications.

\section{References}

1 D'cruz DP, Khamashta MA, Hughes GR. Systemic lupus erythematosus. Lancet 369 (9561), 587-596 (2007).

2 Danchenko N, Satia JA, Anthony MS. Epidemiology of systemic lupus erythematosus: a comparison of worldwide disease burden. Lupus 15(5), 308-318 (2006).

3 Nelson-Piercy C. Handbook of Obstetric Medicine (Third Edition). Informa Healthcare, London, UK, 140-145 (2006).
4 Madazli R, Bulut B, Erenel H, Gezer A, Guralp O. Systemic lupus erythematosus and pregnancy. J. Obstet. Gynaecol. 30(1), 17-20 (2010).

5 Smyth A, Oliveira GH, Lahr BD, Bailey KR, Norby SM, Garovic VD. A systematic review and meta-analysis of pregnancy outcomes in patients with systemic lupus erythematosus and lupus nephritis. Clin. J. Am. Soc. Nephrol. 5(11), 2060-2068 (2010).

6 Dorling J. Centre for Maternal and Child Enquiries (CMACE) Perinatal Mortality
2008: United Kingdom. CMACE, London, UK (2010).

7 Kontaki E, Boumpas DT. Innate immunity in systemic lupus erythematosus: sensing endogenous nucleic acids. J. Autoimmun. 35(3), 206-211 (2010).

8 Veenstra Van Nieuwenhoven AL, Heineman MJ, Faas MM. The immunology of successful pregnancy. Hum. Reprod. Update 9(4), 347-357 (2003).

9 Ohkura N, Sakaguchi S. Regulatory $\mathrm{T}$ cells: roles of $\mathrm{T}$ cell receptor for 
their development and function. Semin. Immunopathol. 32(2), 95-106 (2010).

10 Barrett JH, Brennan P, Fiddler M, Silman AJ. Does rheumatoid arthritis remit during pregnancy and relapse postpartum? Results from a nationwide study in the United Kingdom performed prospectively from late pregnancy. Arthritis Rheum. 42(6), 1219-1227 (1999).

11 Finkelsztejn A, Brooks JB, Paschoal FM Jr, Fragoso YD. What can we really tell women with multiple sclerosis regarding pregnancy? A systematic review and meta-analysis of the literature. BJOG 118(7), 790-797 (2011).

12 Medawar PB. Some immunological and endocrinological problems raised by the evolution of viviparity in vertebrates. Some immunological and endocrinological problems raised by the evolution of viviparity in vertebrates. $7,320-338$ (1953).

13 Chaouat G, Kolb JP, Wegmann TG. The murine placenta as an immunological barrier between the mother and the fetus. Immunol. Rev. 75, 31-60 (1983).

14 Luppi P. How immune mechanisms are affected by pregnancy. Vaccine 21(24), 3352-3357 (2003).

15 Lyall F. The human placental bed revisited. Placenta 23(8-9), 555-562 (2002).

16 Yoshinaga K. Research on blastocyst implantation essential factors (BIEFs). $\mathrm{Am}$. J. Reprod. Immunol. 63(6), 413-424 (2010).

17 Dimitriadis E, Nie G, Hannan NJ, Paiva P, Salamonsen LA. Local regulation of implantation at the human fetal-maternal interface. Int. J. Dev. Biol. 54(2-3), 313-322 (2010).

18 Moffett-King A. Natural killer cells and pregnancy. Nat. Rev. Immunol. 2(9), 656-663 (2002).

19 Abrahams VM, Kim YM, Straszewski SL, Romero R, Mor G. Macrophages and apoptotic cell clearance during pregnancy. Am. J. Reprod. Immunol. 51(4), 275-282 (2004).

20 Tabiasco J, Rabot M, Aguerre-Girr M et al. Human decidual NK cells: unique phenotype and functional properties - a review. Placenta 27(Suppl. A), S34-S39 (2006).

21 Cartwright JE, Fraser R, Leslie K, Wallace AE, James JL. Remodelling at the maternal-fetal interface: relevance to human pregnancy disorders. Reproduction 140 (6), 803-813 (2010).
22 Nagamatsu T, Schust DJ. The contribution of macrophages to normal and pathological pregnancies. Am. J. Reprod. Immunol. 63(6), 460-471 (2010).

23 Mizuno M, Aoki K, Kimbara T. Functions of macrophages in human decidual tissue in early pregnancy. Am. J. Reprod. Immunol. 31(4), 180-188 (1994).

24 Heikkinen J, Mottonen M, Komi J, Alanen A, Lassila O. Phenotypic characterization of human decidual macrophages. Clin. Exp. Immunol. 131(3), 498-505 (2003).

25 Heikkinen J, Mottonen M, Alanen A, Lassila O. Phenotypic characterization of regulatory T cells in the human decidua. Clin. Exp. Immunol. 136(2), 373-378 (2004).

26 Munn DH, Zhou M, Attwood JT et al. Prevention of allogeneic fetal rejection by tryptophan catabolism. Science 281(5380), 1191-1193 (1998).

27 Smith SD, Dunk CE, Aplin JD, Harris LK, Jones RL. Evidence for immune cell involvement in decidual spiral arteriole remodeling in early human pregnancy. Am. J. Pathol. 174(5), 1959-1971 (2009).

28 Trundley A, Moffett A. Human uterine leukocytes and pregnancy. Tissue Antigens 63(1), 1-12 (2004).

29 Cederbom L, Hall H, Ivars F. CD $4^{+} \mathrm{CD} 25^{+}$ regulatory $\mathrm{T}$ cells down-regulate costimulatory molecules on antigenpresenting cells. Eur. J. Immunol. 30(6), 1538-1543 (2000).

30 Walker MR, Kasprowicz DJ, Gersuk VH et al. Induction of FOXP3 and acquisition of $\mathrm{T}$ regulatory activity by stimulated human $\mathrm{CD} 4{ }^{+} \mathrm{CD} 25-\mathrm{T}$ cells. J. Clin. Invest. 112(9), 1437-1443 (2003).

31 Stephens LA, Mottet C, Mason D, Powrie F. Human $\mathrm{CD} 4\left(^{+}\right) \mathrm{CD} 25\left(^{+}\right)$thymocytes and peripheral $\mathrm{T}$ cells have immune suppressive activity in vitro. Eur. J. Immunol. 31(4), 1247-1254 (2001).

32 Hara M, Kingsley CI, Niimi M et al. IL-10 is required for regulatory $\mathrm{T}$ cells to mediate tolerance to alloantigens in vivo. J. Immunol. 166(6), 3789-3796 (2001).

33 Fontenot JD, Gavin MA, Rudensky AY. FOXP3 programs the development and function of $\mathrm{CD} 4{ }^{+} \mathrm{CD} 25^{+}$regulatory $\mathrm{T}$ cells. Nat. Immunol. 4(4), 330-336 (2003).

34 Hori S, Nomura T, Sakaguchi S. Control of regulatory $\mathrm{T}$ cell development by the transcription factor FOXP3. Science 299(5609), 1057-1061 (2003).

35 Khattri R, Cox T, Yasayko SA, Ramsdell F. An essential role for Scurfin in CD $4{ }^{+} \mathrm{CD} 25^{+} \mathrm{T}$ regulatory cells. $\mathrm{Nat}$. Immunol. 4(4), 337-342 (2003).
36 Roncador G, Brown PJ, Maestre L et al. Analysis of FOXP3 protein expression in human $\mathrm{CD} 4{ }^{+} \mathrm{CD} 25^{+}$regulatory $\mathrm{T}$ cells at the single-cell level. Eur. J. Immunol. 35(6), 1681-1691 (2005).

37 Powell BR, Buist NR, Stenzel P. An X-linked syndrome of diarrhea, polyendocrinopathy, and fatal infection in infancy. J. Pediatr. 100(5), 731-737 (1982).

38 Seddiki N, Santner-Nanan B, Martinson J et al. Expression of interleukin (IL)-2 and IL-7 receptors discriminates between human regulatory and activated $\mathrm{T}$ cells. J. Exp. Med. 203(7), 1693-1700 (2006).

39 Liu W, Putnam AL, Xu-Yu Z et al. CD127 expression inversely correlates with FOXP3 and suppressive function of human $\mathrm{CD}^{+}$ Treg cells. J. Exp. Med. 203(7), 1701-1711 (2006).

40 Hartigan-O'Connor DJ, Poon C, Sinclair E, Mccune JM. Human $\mathrm{CD}^{+}{ }^{+}$regulatory $\mathrm{T}$ cells express lower levels of the IL-7 receptor $\alpha$ chain (CD127), allowing consistent identification and sorting of live cells. J. Immunol. Methods 319(1-2), 41-52 (2007).

41 Seddiki N, Santner-Nanan B, Tangye SG et al. Persistence of naive CD45RA ${ }^{+}$ regulatory $\mathrm{T}$ cells in adult life. Blood 107(7), 2830-2838 (2006).

42 Valmori D, Merlo A, Souleimanian NE, Hesdorffer CS, Ayyoub M. A peripheral circulating compartment of natural naive CD4 Tregs. J. Clin. Invest. 115(7), 1953-1962 (2005).

43 Fritzsching B, Oberle N, Pauly E et al. Naive regulatory T cells: a novel subpopulation defined by resistance toward CD95L-mediated cell death. Blood 108(10), 3371-3378 (2006).

44 Vignali DA, Collison LW, Workman CJ. How regulatory T cells work. Nat. Rev. Immunol. 8(7), 523-532 (2008).

45 Sakaguchi S, Miyara M, Costantino $\mathrm{CM}, \mathrm{Hafler} \mathrm{DA}$. FOXP3 ${ }^{+}$regulatory $\mathrm{T}$ cells in the human immune system. Nat. Rev. Immunol. 10 (7), 490-500 (2010).

46 Miyara M, Yoshioka Y, Kitoh A et al. Functional delineation and differentiation dynamics of human $\mathrm{CD}^{+}{ }^{+} \mathrm{T}$ cells expressing the FOXP3 transcription factor. Immunity 30 (6), 899-911 (2009).

47 Ito M, Nakashima A, Hidaka T et al. A role for IL-17 in induction of an inflammation at the fetomaternal interface in preterm labour. J. Reprod. Immunol. 84(1), 75-85 (2010). 
48 Mjosberg J, Berg G, Jenmalm MC, Ernerudh J. FOXP3 ${ }^{+}$regulatory $\mathrm{T}$ cells and $\mathrm{T}$ helper $1, \mathrm{~T}$ helper 2 , and $\mathrm{T}$ helper 17 cells in human early pregnancy decidua. Biol. Reprod. 82(4), 698-705 (2010).

49 Tilburgs T, Roelen DL, Van Der Mast BJ et al. Differential distribution of CD4(+) CD25(bright) and CD8(+)CD28(-) T-cells in decidua and maternal blood during human pregnancy. Placenta 27(Suppl. A), S47-S53 (2006).

50 Mold JE, Michaelsson J, Burt TD et al. Maternal alloantigens promote the development of tolerogenic fetal regulatory $\mathrm{T}$ cells in utero. Science 322(5907), 1562-1565 (2008).

51 Takahata Y, Nomura A, Takada $\mathrm{H}$ et al. $\mathrm{CD} 25^{+} \mathrm{CD}^{+} \mathrm{T}$ cells in human cord blood: an immunoregulatory subset with naive phenotype and specific expression of forkhead box p3 (FOXP3) gene. Exp. Hematol. 32(7), 622-629 (2004).

52 Aluvihare VR, Kallikourdis M, Betz AG. Regulatory $\mathrm{T}$ cells mediate maternal tolerance to the fetus. Nat. Immunol. 5(3), 266-271 (2004).

53 Arruvito L, Sanz M, Banham AH, Fainboim L. Expansion of $\mathrm{CD}^{+}{ }^{+} \mathrm{CD} 25^{+}$and $\mathrm{FOXP}^{+}$regulatory $\mathrm{T}$ cells during the follicular phase of the menstrual cycle: implications for human reproduction. J. Immunol. 178(4), 2572-2578 (2007).

54 Robertson SA, Guerin LR, Moldenhauer LM, Hayball JD. Activating T regulatory cells for tolerance in early pregnancy the contribution of seminal fluid. J. Reprod. Immunol. 83(1-2), 109-116 (2009).

55 Guerin LR, Prins JR, Robertson SA. Regulatory T-cells and immune tolerance in pregnancy: a new target for infertility treatment? Hum. Reprod. Update 15(5), 517-535 (2009).

56 Schumacher A, Brachwitz N, Sohr S et al. Human chorionic gonadotropin attracts regulatory $\mathrm{T}$ cells into the fetal-maternal interface during early human pregnancy. J. Immunol. 182(9), 5488-5497 (2009).

57 Wegmann TG, Lin H, Guilbert L, Mosmann TR. Bidirectional cytokine interactions in the maternal-fetal relationship: is successful pregnancy a Th2 phenomenon? Immunol. Today 14(7), 353-356 (1993).

58 Raghupathy R. Th1-type immunity is incompatible with successful pregnancy. Immunol. Today 18(10), 478-482 (1997).
59 Challis JR, Lockwood CJ, Myatt L, Norman JE, Strauss JF 3rd, Petraglia F. Inflammation and pregnancy. Reprod. Sci. 16(2), 206-215 (2009).

60 Chaouat G, Ledee-Bataille N, Dubanchet S, Zourbas S, Sandra O, Martal J. Th1/Th2 paradigm in pregnancy: paradigm lost? Cytokines in pregnancy/ early abortion: reexamining the Th1/Th2 paradigm. Int. Arch. Allergy. Immunol. 134(2), 93-119 (2004).

61 Bates MD, Quenby S, Takakuwa K, Johnson PM, Vince GS. Aberrant cytokine production by peripheral blood mononuclear cells in recurrent pregnancy loss? Hum. Reprod. 17(9), 2439-2444 (2002).

62 Somerset DA, Zheng Y, Kilby MD, Sansom DM, Drayson MT. Normal human pregnancy is associated with an elevation in the immune suppressive $\mathrm{CD} 25^{+} \mathrm{CD} 4{ }^{+}$ regulatory T-cell subset. Immunology 112(1), 38-43 (2004).

63 Sasaki Y, Sakai M, Miyazaki S, Higuma S, Shiozaki A, Saito S. Decidual and peripheral blood $\mathrm{CD} 4{ }^{+} \mathrm{CD} 25^{+}$ regulatory $\mathrm{T}$ cells in early pregnancy subjects and spontaneous abortion cases. Mol. Hum. Reprod. 10(5), 347-353 (2004).

64 Chirico DEA. Predictors of pregnancy complications in women with systemic lupus erythematosus. BJOG 116 , 1407-1408 (2009).

65 Xiong H, Zhou C, Qi G. Proportional changes of $\mathrm{CD}^{+}{ }^{+} \mathrm{CD} 25^{+} \mathrm{FOXP} 3^{+}$ regulatory $\mathrm{T}$ cells in maternal peripheral blood during pregnancy and labor at term and preterm. Clin. Invest. Med. 33(6), E422 (2010).

66 Mjosberg J, Svensson J, Johansson E et al. Systemic reduction of functionally suppressive $\mathrm{CD} 4{ }^{\mathrm{dim}} \mathrm{CD} 25^{\text {high }} \mathrm{FOXP} 3{ }^{+}$Tregs in human second trimester pregnancy is induced by progesterone and $17 \beta$-estradiol. J. Immunol. 183(1), 759-769 (2009).

67 Leber A, Teles A, Zenclussen AC. Regulatory $\mathrm{T}$ cells and their role in pregnancy. Am. J. Reprod. Immunol. 63(6), 445-459 (2010).

68 Crome SQ, Wang AY, Levings MK. Translational mini-review series on Th17 cells: function and regulation of human T helper 17 cells in health and disease. Clin. Exp. Immunol. 159(2), 109-119 (2010).

69 Saito S, Nakashima A, Shima T, Ito M. Th1/Th2/Th17 and regulatory T-cell paradigm in pregnancy. Am. J. Reprod. Immunol. 63(6), 601-610 (2010).
70 Akbar AN, Vukmanovic-Stejic M, Taams LS, Macallan DC. The dynamic coevolution of memory and regulatory $\mathrm{CD}^{+}$ T cells in the periphery. Nat. Rev. Immunol. 7(3), 231-237 (2007).

71 Chen W, Jin W, Hardegen N et al. Conversion of peripheral $\mathrm{CD} 4{ }^{+} \mathrm{CD} 25$ naive $\mathrm{T}$ cells to $\mathrm{CD} 4{ }^{+} \mathrm{CD} 25^{+}$regulatory $\mathrm{T}$ cells by TGF- $\beta$ induction of transcription factor FOXP3. J. Exp. Med. 198(12), 1875-1886 (2003).

72 Bettelli E, Carrier Y, Gao W et al. Reciprocal developmental pathways for the generation of pathogenic effector Th17 and regulatory T cells. Nature 441(7090), 235-238 (2006).

73 Sharma MD, Hou DY, Liu Y et al. Indoleamine 2,3-dioxygenase controls conversion of FOXP3 ${ }^{+}$Tregs to Th17-like cells in tumor-draining lymph nodes. Blood 113(24), 6102-6111 (2009).

74 Nakashima A, Ito M, Yoneda S, Shiozaki A, Hidaka T, Saito S. Circulating and decidual Th17 cell levels in healthy pregnancy. Am. J. Reprod. Immunol. 63(2), 104-109 (2010).

75 Santner-Nanan B, Peek MJ, Khanam R et al. Systemic increase in the ratio between $\mathrm{FOXP}^{+}$and IL-17-producing $\mathrm{CD}^{+}{ }^{+} \mathrm{T}$ cells in healthy pregnancy but not in preeclampsia. J. Immunol. 183(11), 7023-7030 (2009).

76 Crispin JC, Kyttaris V, Juang YT, Tsokos GC. Systemic lupus erythematosus: new molecular targets. Ann. Rheum. Dis. 66(Suppl. 3), iii65-iii69 (2007).

77 Isenberg DA, Manson JJ, Ehrenstein MR, Rahman A. Fifty years of anti-ds DNA antibodies: are we approaching journey's end? Rheumatology (Oxford) 46(7), 1052-1056 (2007).

78 Sakaguchi S, Fukuma K, Kuribayashi K, Masuda T. Organ-specific autoimmune diseases induced in mice by elimination of $\mathrm{T}$ cell subset. I. Evidence for the active participation of $\mathrm{T}$ cells in natural self-tolerance; deficit of a $\mathrm{T}$ cell subset as a possible cause of autoimmune disease. J. Exp. Med. 161(1), 72-87 (1985).

79 Sakaguchi S. Naturally arising CD $4^{+}$ regulatory $\mathrm{T}$ cells for immunologic self-tolerance and negative control of immune responses. Ann. Rev. Immunol. 22, 531-562 (2004).

80 Asano M, Toda M, Sakaguchi N, Sakaguchi S. Autoimmune disease as a consequence of developmental abnormality of a T cell subpopulation. J. Exp. Med. 184(2), 387-396 (1996). 
81 Hayashi T, Hasegawa K, Adachi C. Elimination of CD4(+) CD25( $\left(^{+}\right) \mathrm{T}$ cell accelerates the development of glomerulonephritis during the preactive phase in autoimmune-prone female NZB x NZW F mice. Int. J. Exp. Pathol. 86(5), 289-296 (2005).

82 Scalapino KJ, Tang Q, Bluestone JA, Bonyhadi ML, Daikh DI. Suppression of disease in New Zealand Black/New Zealand White lupus-prone mice by adoptive transfer of ex vivo expanded regulatory T cells. J. Immunol. 177(3), 1451-1459 (2006).

83 Hsu WT, Suen JL, Chiang BL. The role of CD4CD25 T cells in autoantibody production in murine lupus. Clin. Exp. Immunol. 145(3), 513-519 (2006).

84 Monk CR, Spachidou M, Rovis F et al. MRL/Mp CD 4 ${ }^{+}$, CD25- T cells show reduced sensitivity to suppression by $\mathrm{CD} 4^{+}, \mathrm{CD} 25^{+}$regulatory $\mathrm{T}$ cells in vitro: a novel defect of $\mathrm{T}$ cell regulation in systemic lupus erythematosus. Arthritis Rheum. 52(4), 1180-1184 (2005).

85 Brunkow ME, Jeffery EW, Hjerrild KA et al. Disruption of a new forkhead/ winged-helix protein, scurfin, results in the fatal lymphoproliferative disorder of the scurfy mouse. Nat. Genet. 27(1), 68-73 (2001).

86 Riemekasten G, Langnickel D, Enghard P et al. Intravenous injection of a D1 protein of the Smith proteins postpones murine lupus and induces type 1 regulatory T cells. J. Immunol. 173(9), 5835-5842 (2004).

87 Kang HK, Liu M, Datta SK. Low-dose peptide tolerance therapy of lupus generates plasmacytoid dendritic cells that cause expansion of autoantigen-specific regulatory $\mathrm{T}$ cells and contraction of inflammatory Th17 cells. J. Immunol. 178(12), 7849-7858 (2007).

88 Horwitz DA. Regulatory T cells in systemic lupus erythematosus: past, present and future. Arthritis Res. Ther. 10(6), 227 (2008).

89 Barath S, Aleksza M, Tarr T, Sipka S, Szegedi G, Kiss E. Measurement of natural $\left(\mathrm{CD} 4{ }^{+} \mathrm{CD} 25^{\text {high }}\right)$ and inducible $\left(\mathrm{CD} 4{ }^{+} \mathrm{IL}-10^{+}\right)$regulatory $\mathrm{T}$ cells in patients with systemic lupus erythematosus. Lupus 16(7), 489-496 (2007).

90 Crispin JC, Martinez A, Alcocer-Varela J. Quantification of regulatory $\mathrm{T}$ cells in patients with systemic lupus erythematosus. J. Autoimmun. 21(3), 273-276 (2003).

91 Barath S, Soltesz P, Kiss E et al. The severity of systemic lupus erythematosus negatively correlates with the increasing number of CD $4^{+} \mathrm{CD} 25$ ( $^{\text {high }}$ ) $\mathrm{FOXP}^{+}$regulatory $\mathrm{T}$ cells during repeated plasmapheresis treatments of patients. Autoimmunity 40 (7), 521-528 (2007).

92 Miyara M, Amoura Z, Parizot C et al. Global natural regulatory $\mathrm{T}$ cell depletion in active systemic lupus erythematosus. J. Immunol. 175(12), 8392-8400 (2005).

93 Valencia X, Yarboro C, Illei G, Lipsky PE. Deficient $\mathrm{CD} 4^{+} \mathrm{CD} 25^{\text {high }} \mathrm{T}$ regulatory cell function in patients with active systemic lupus erythematosus. J. Immunol. 178(4), 2579-2588 (2007).

94 Bonelli M, Savitskaya A, Von Dalwigk K et al. Quantitative and qualitative deficiencies of regulatory $T$ cells in patients with systemic lupus erythematosus (SLE). Int. Immunol. 20 (7), 861-868 (2008).

95 Zhang B, Zhang X, Tang FL, Zhu LP, Liu Y, Lipsky PE. Clinical significance of increased $\mathrm{CD}^{+}{ }^{+} \mathrm{CD} 25-\mathrm{FOXP} 3+{ }^{+} \mathrm{T}$ cells in patients with new-onset systemic lupus erythematosus. Ann. Rheum. Dis. 67(7), 1037-1040 (2008).

96 Venigalla RK, Tretter T, Krienke S et al. Reduced $\mathrm{CD}^{+}, \mathrm{CD} 25^{-} \mathrm{T}$ cell sensitivity to the suppressive function of $\mathrm{CD}^{+}$, $\mathrm{CD} 25^{\text {high }}$, CD127-/low regulatory $\mathrm{T}$ cells in patients with active systemic lupus erythematosus. Arthritis Rheum. 58(7), 2120-2130 (2008).

97 Franz B, Fritzsching B, Riehl A et al. Low number of regulatory $\mathrm{T}$ cells in skin lesions of patients with cutaneous lupus erythematosus. Arthritis Rheum. 56(6), 1910-1920 (2007).

98 Yates J, Whittington A, Mitchell P, Lechler RI, Lightstone L, Lombardi G. Natural regulatory $\mathrm{T}$ cells: number and function are normal in the majority of patients with lupus nephritis. Clin. Exp. Immunol. 153(1), 44-55 (2008).

99 Mesquita D, de Melo Cruvinel W, Araujo J et al. Systemic lupus erythematosus exhibits a dynamic and continuum spectrum of effector/regulatory T cells. Scand. J. Rheumatol. 40(1), 41-50 (2011).

100 Klein S, Kretz CC, Krammer PH, Kuhn A. CD127(low/-) and FOXP3 $\left(^{+}\right)$expression levels characterize different regulatory T-cell populations in human peripheral blood. J. Invest. Dermatol. 130 (2), 492-499 (2010).

101 Sfikakis PP, Souliotis VL, Fragiadaki KG, Moutsopoulos HM, Boletis JN, Theofilopoulos AN. Increased expression of the FOXP3 functional marker of regulatory T cells following B cell depletion with rituximab in patients with lupus nephritis. Clin. Immunol. 123(1), 66-73 (2007).
102 Thornton AM, Shevach EM. CD $4^{+} \mathrm{CD} 25^{+}$ immunoregulatory $\mathrm{T}$ cells suppress polyclonal $\mathrm{T}$ cell activation in vitro by inhibiting interleukin 2 production. J. Exp. Med. 188(2), 287-296 (1998).

103 Takahashi T, Kuniyasu Y, Toda M et al. Immunologic self-tolerance maintained by $\mathrm{CD} 25^{+} \mathrm{CD} 4^{+}$naturally anergic and suppressive $\mathrm{T}$ cells: induction of autoimmune disease by breaking their anergic/suppressive state. Int. Immunol. 10(12), 1969-1980 (1998).

104 Oberle N, Eberhardt N, Falk CS, Krammer PH, Suri-Payer E. Rapid suppression of cytokine transcription in human $\mathrm{CD} 4{ }^{+} \mathrm{CD} 25 \mathrm{~T}$ cells by $\mathrm{CD} 4^{+} \mathrm{FOXP}^{+}{ }^{+}$regulatory $\mathrm{T}$ cells: independence of IL-2 consumption, TGF- $\beta$, and various inhibitors of TCR signaling. J. Immunol. 179(6), 3578-3587 (2007).

105 Grossman WJ, Verbsky JW, Barchet W, Colonna M, Atkinson JP, Ley TJ. Human T regulatory cells can use the perforin pathway to cause autologous target cell death. Immunity 21(4), 589-601 (2004).

106 Garin MI, Chu CC, Golshayan D, Cernuda-Morollon E, Wait R, Lechler RI. Galectin-1: a key effector of regulation mediated by $\mathrm{CD} 4{ }^{+} \mathrm{CD} 25^{+} \mathrm{T}$ cells. Blood 109(5), 2058-2065 (2007).

107 Shevach EM. Mechanisms of foxp $3^{+} \mathrm{T}$ regulatory cell-mediated suppression. Immunity 30(5), 636-645 (2009).

108 Onishi Y, Fehervari Z, Yamaguchi T, Sakaguchi S. FOXP3 ${ }^{+}$natural regulatory $\mathrm{T}$ cells preferentially form aggregates on dendritic cells in vitro and actively inhibit their maturation. Proc. Natl Acad. Sci. USA 105(29), 10113-10118 (2008).

109 DiPaolo RJ, Brinster C, Davidson TS, Andersson J, Glass D, Shevach EM. Autoantigen-specific TGF $\beta$-induced FOXP3 ${ }^{+}$regulatory $\mathrm{T}$ cells prevent autoimmunity by inhibiting dendritic cells from activating autoreactive T cells. J. Immunol. 179(7), 4685-4693 (2007).

110 Xing Q, Wang B, Su H, Cui J, Li J. Elevated Th17 cells are accompanied by $\mathrm{FOXP}^{+}$Treg cells decrease in patients with lupus nephritis. Rheumatol. Int. DOI: $10.1007 /$ s00296-010-1771-0 (2011) (Epub ahead of print).

111 Ma J, Yu J, Tao X, Cai L, Wang J, Zheng SG. The imbalance between regulatory and IL-17-secreting CD $4^{+} \mathrm{T}$ cells in lupus patients. Clin. Rheumatol. 29(11), 1251-1258 (2010). 
112 Becker-Merok A, Eilertsen GO, Nossent JC. Levels of transforming growth factor- $\beta$ are low in systemic lupus erythematosus patients with active disease. J. Rheumatol. 37(10), 2039-2045 (2010).

113 Aggarwal N, Raveendran A, Suri V, Chopra S, Sikka P, Sharma A. Pregnancy outcome in systemic lupus erythematosus: Asia's largest single centre study. Arch. Gynecol. Obstet. 284(2), 281-285 (2010).

114 Clowse ME, Jamison M, Myers E, James AH. A national study of the complications of lupus in pregnancy. Am. J. Obstet. Gynecol. 199(2), 127 e121-e126 (2008).

115 Ogishima D, Matsumoto T, Nakamura Y, Yoshida K, Kuwabara Y. Placental pathology in systemic lupus erythematosus with antiphospholipid antibodies. Pathol. Int. 50(3), 224-229 (2000).

116 Costa AM, Maximiano EB, Avvad-Portari E, Jesus NR, Levy RA, Porto LC. Contractile cells and fibrillin-1 distribution is disturbed in terminal villi of placentae from patients with preeclampsia and systemic lupus erythematosus. Placenta 27(2-3), 234-243 (2006).

117 Nayar R, Lage JM. Placental changes in a first trimester missed abortion in maternal systemic lupus erythematosus with antiphospholipid syndrome; a case report and review of the literature. Hum. Pathol. 27(2), 201-206 (1996).

118 Ornoy A, Chen L, Silver RM, Miller RK. Maternal autoimmune diseases and immunologically induced embryonic and fetoplacental damage. Birth Defects Res. A. Clin. Mol. Teratol. 70(6), 371-381 (2004).

119 Ornoy A, Yacobi S, Matalon ST et al. The effects of antiphospholipid antibodies obtained from women with SLE/APS and associated pregnancy loss on rat embryos and placental explants in culture. Lupus 12(7), 573-578 (2003).

120 Schwartz N, Shoenfeld Y, Barzilai O et al. Reduced placental growth and hCG secretion in vitro induced by antiphospholipid antibodies but not by anti-Ro or anti-La: studies on sera from women with SLE/PAPS. Lupus 16(2), 110-120 (2007).

121 Clowse ME. Lupus activity in pregnancy. Rheum. Dis. Clin. North Am. 33(2), 237-252, v (2007).

122 Gupta R, Deepanjali S, Kumar A et al. A comparative study of pregnancy outcomes and menstrual irregularities in northern Indian patients with systemic lupus erythematosus and rheumatoid arthritis. Rheumatol. Int. 30(12), 1581-1585 (2010).
123 Clowse ME, Magder LS, Witter F, Petri M. The impact of increased lupus activity on obstetric outcomes. Arthritis Rheum. 52(2), 514-521 (2005).

124 Wang WJ, Hao CF, Qu QL, Wang X, Qiu LH, Lin QD. The deregulation of regulatory $\mathrm{T}$ cells on interleukin-17producing $T$ helper cells in patients with unexplained early recurrent miscarriage. Hum. Reprod. 25(10), 2591-2596 (2010).

125 Arruvito L, Sotelo AI, Billordo A, Fainboim L. A physiological role for inducible FOXP3 $\left(^{+}\right)$Treg cells. Lessons from women with reproductive failure. Clin. Immunol. 136(3), 432-441 (2010).

126 Liu YS, Wu L, Tong XH et al. Study on the relationship between Th17 cells and unexplained recurrent spontaneous abortion. Am. J. Reprod. Immunol. 65(5), 503-511 (2010).

127 Yang H, Qiu L, Chen G, Ye Z, Lu C, Lin Q. Proportional change of $\mathrm{CD} 4{ }^{+} \mathrm{CD} 25^{+}$ regulatory $\mathrm{T}$ cells in decidua and peripheral blood in unexplained recurrent spontaneous abortion patients. Fertil. Steril. 89(3), 656-661 (2008).

128 Wang WJ, Hao CF, Yi L et al. Increased prevalence of T helper 17 (Th17) cells in peripheral blood and decidua in unexplained recurrent spontaneous abortion patients. J. Reprod. Immunol. 84(2), 164-170 (2010).

129 Shima T, Sasaki Y, Itoh M et al. Regulatory $T$ cells are necessary for implantation and maintenance of early pregnancy but not late pregnancy in allogeneic mice. J. Reprod. Immunol. 85(2), 121-129 (2010).

130 Zenclussen AC, Gerlof K, Zenclussen ML et al. Abnormal T-cell reactivity against paternal antigens in spontaneous abortion: adoptive transfer of pregnancy-induced $\mathrm{CD} 4{ }^{+} \mathrm{CD} 25^{+} \mathrm{T}$ regulatory cells prevents fetal rejection in a murine abortion model. Am. J. Pathol. 166(3), 811-822 (2005).

131 Petri M. Hopkins Lupus Pregnancy Center: 1987 to 1996. Rheum. Dis. Clin. North. Am. 23(1), 1-13 (1997).

132 Chakravarty EF, Colon I, Langen ES et al. Factors that predict prematurity and preeclampsia in pregnancies that are complicated by systemic lupus erythematosus. Am. J. Obstet. Gynecol. 192(6), 1897-1904 (2005).

133 Crocker I. Gabor Than Award Lecture 2006: pre-eclampsia and villous trophoblast turnover: perspectives and possibilities. Placenta 28(Suppl. A), S4-S13 (2007).
134 Saito S, Shiozaki A, Nakashima A, Sakai $\mathrm{M}$, Sasaki Y. The role of the immune system in preeclampsia. Mol. Asp. Med. 28(2), 192-209 (2007).

$135 \mathrm{Hu} \mathrm{D}$, Chen Y, Zhang W, Wang H, Wang Z, Dong M. Alteration of peripheral $\mathrm{CD} 4{ }^{+} \mathrm{CD} 25^{+}$regulatory $\mathrm{T}$ lymphocytes in pregnancy and pre-eclampsia. Acta. Obstet. Gynecol. Scand. 87(2), 190-194 (2008).

136 Paeschke S, Chen F, Horn N et al. Pre-eclampsia is not associated with changes in the levels of regulatory $\mathrm{T}$ cells in peripheral blood. Am. J. Reprod. Immunol. 54(6), 384-389 (2005).

137 Steinborn A, Haensch GM, Mahnke K et al. Distinct subsets of regulatory $\mathrm{T}$ cells during pregnancy: is the imbalance of these subsets involved in the pathogenesis of preeclampsia? Clin. Immunol. 129(3), 401-412 (2008).

138 Sasaki Y, Darmochwal-Kolarz D, Suzuki D et al. Proportion of peripheral blood and decidual CD4(+) CD25(bright) regulatory $\mathrm{T}$ cells in pre-eclampsia. Clin. Exp. Immunol. 149(1), 139-145 (2007).

139 Toldi G, Rigo J Jr, Stenczer B, Vasarhelyi $B$, Molvarec A. Increased prevalence of IL-17-producing peripheral blood lymphocytes in pre-eclampsia. Am. J. Reprod. Immunol. 66(3), 223-229 (2011).

140 Foidart JM, Schaaps JP, Chantraine F, Munaut C, Lorquet S. Dysregulation of anti-angiogenic agents (sFlt-1, PLGF, and sEndoglin) in preeclampsia - a step forward but not the definitive answer. J. Reprod. Immunol. 82(2), 106-111 (2009).

141 Lamarca BD, Ryan MJ, Gilbert JS, Murphy SR, Granger JP. Inflammatory cytokines in the pathophysiology of hypertension during preeclampsia. Curr. Hypertens. Rep. 9(6), 480-485 (2007).

142 Maynard SE, Min JY, Merchan J et al. Excess placental soluble fms-like tyrosine kinase 1 (sFlt1) may contribute to endothelial dysfunction, hypertension, and proteinuria in preeclampsia. J. Clin. Invest. 111(5), 649-658 (2003).

143 Qazi U, Lam C, Karumanchi SA, Petri M. Soluble Fms-like tyrosine kinase associated with preeclampsia in pregnancy in systemic lupus erythematosus. J. Rheumatol. 35(4), 631-634 (2008).

144 Motomura Y, Kanbayashi H, Khan WI et al. The gene transfer of soluble VEGF type I receptor (Flt-1) attenuates peritoneal fibrosis formation in mice but not soluble TGF- $\beta$ type II receptor gene transfer. $A m$. J. Phys. 288(1), G143-150 (2005). 
145 Salmon JE, Heuser C, Triebwasser M et al. Mutations in complement regulatory proteins predispose to preeclampsia: a genetic analysis of the PROMISSE cohort. PLoS Med. 8(3), e1001013 (2011).

146 Girardi G, Yarilin D, Thurman JM, Holers VM, Salmon JE. Complement activation induces dysregulation of angiogenic factors and causes fetal rejection and growth restriction. J. Exp. Med. 203(9), 2165-2175 (2006).

147 Forger F, Marcoli N, Gadola S, Moller B, Villiger PM, Ostensen M. Pregnancy induces numerical and functional changes of $\mathrm{CD} 4{ }^{+} \mathrm{CD} 25^{\text {high }}$ regulatory $\mathrm{T}$ cells in patients with rheumatoid arthritis. Ann. Rheum. Dis. 67(7), 984-990 (2008).

148 Forger F, Villiger PM, Ostensen M. Pregnancy in patients with ankylosing spondylitis: do regulatory $\mathrm{T}$ cells play a role? Arthritis Rheum. 61(2), 279-283 (2009).

149 Allan SE, Broady R, Gregori S et al. CD $4^{+}$ T-regulatory cells: toward therapy for human diseases. Immunol. Rev. 223, 391-421 (2008).
150 Gao W, Lu Y, El Essawy B, Oukka M, Kuchroo VK, Strom TB. Contrasting effects of cyclosporine and rapamycin in de novo generation of alloantigen-specific regulatory T cells. Am. J. Transplant 7(7), 1722-1732 (2007).

151 Jee Y, Piao WH, Liu R et al. CD4(+) $\left.\mathrm{CD} 25^{+}\right)$regulatory $\mathrm{T}$ cells contribute to the therapeutic effects of glatiramer acetate in experimental autoimmune encephalomyelitis. Clin. Immunol. 125(1), 34-42 (2007).

152 Tao R, De Zoeten EF, Ozkaynak E et al. Deacetylase inhibition promotes the generation and function of regulatory $\mathrm{T}$ cells. Nat. Med. 13(11), 1299-1307 (2007).

153 Zenclussen AC. CD4(+) CD25+ T regulatory cells in murine pregnancy. J. Reprod. Immunol. 65(2), 101-110 (2005).

154 Clark DA, Fernandes J, Banwatt D. Prevention of spontaneous abortion in the CBA x DBA/2 mouse model by intravaginal TGF- $\beta$ and local recruitment of $\mathrm{CD} 4^{+} 8^{+} \mathrm{FOXP}^{+}$cells. Am. J. Reprod. Immunol. 59(6), 525-534 (2008).
155 Scarpellini F, Sbracia M. Use of granulocyte colony-stimulating factor for the treatment of unexplained recurrent miscarriage: a randomised controlled trial. Hum. Reprod. 24(11), 2703-2708 (2009).

156 Kato Y, Kuwabara T, Itoh T et al. A possible relationship between abortions and placental embolism in pregnant rabbits given human granulocyte colonystimulating factor. J. Toxicol. Sci. 26(1), 39-50 (2001).

157 Suntharalingam G, Perry MR, Ward S et al. Cytokine storm in a Phase 1 trial of the anti-CD28 monoclonal antibody TGN1412. N. Engl. J. Med. 355(10), 1018-1028 (2006).

\section{Website}

201 Government National Statistics, UK. News Release. 1 in 13 live births born in England and Wales are born preterm (2007) www.statistics.gov.uk/pdfdir/preterm0507. pdf 